\title{
Determinants of shipbuilding industry competitive factors and institutional model analysis
}

\author{
Aziz Ikhsan Bachtiar ${ }^{a^{*}}$, Marimin $^{\mathrm{b}}$, Luky Adrianto $^{\mathrm{c}}$ and Romie Oktovianus Bura ${ }^{\mathrm{d}}$
}

\begin{tabular}{l}
\hline C H R O N I C L E \\
\hline Article history: \\
Received October 28, 2020 \\
Received in revised format: \\
October 29, 2020 \\
Accepted November 172020 \\
Available online \\
November 17,2020 \\
\hline Keywords: \\
Technology Transfer \\
Competitiveness \\
Shipbuilding Industry \\
ISM \\
Industrial Cluster
\end{tabular}

${ }^{a}$ School of Business Bogor Agricultural University (IPB University), Bogor, Indonesia

${ }^{b}$ Faculty of Engineering and Agricultural Technology (IPB University), Bogor, Indonesia

${ }^{c}$ Faculty of Fisheries and Marine Science (IPB University) Bogor, Indonesia

${ }^{d}$ Faculty of Defense Technology Indonesian Defense University (Unhan) Bogor, Indonesia

\section{Introduction}

As an archipelagic country, Indonesia needs quite a lot of ships for trade and defense, where merchant ships have an important function, namely trade and fishing transportation. Also, warships are used for the enforcement of sovereignty from the threats from foreign countries and the law at sea as well as for the diplomatic function of the Indonesian Navy (Wulan, 2020; Arshad et al., 2020). National security is interpreted as the state's ability to protect the national assets from the threats including Indonesia's territorial territory. The new shipbuilding has two main segments, namely the commercial ship segment and the warship segment. According to Lloyd's List Intelligence (2018), new ship deliveries experienced a growth of $3.5 \%$ for the next five years. European countries produce more passenger ships, while Korea receives more orders

* Corresponding author

E-mail address: azisbahtiar2020@gmail.com (A. I. Bachtiar)

(C) 2021 by the authors; licensee Growing Science, Canada. doi: $10.5267 /$ j.dsl.2020.11.004

\begin{abstract}
A B S T R A C T
The development of the shipbuilding industry is expected to meet the needs of the Indonesian Navy and the commercial vessels, and to support Indonesia's marine policy. The purpose of this study is to see the Shipbuilding industry Competitiveness, the influence of Technology Transfer to the Shipbuilding industry Competitiveness, and the influence of the industrial clusters on the Shipbuilding industry Competitiveness, as well as to analyze the institutional model of the Equation Modeling (SEM) for the model causality testing, and the Interpretative Structural Modeling (ISM) for the institutional model of the competitiveness of the Shipbuilding Industry. This study uses the primary data, namely a survey of defense industry players, the national industry, the defense equipment users, the government institutions, the research institutes, and the universities that are determined purposively. ISM data are obtained from questionnaires and Forum Group Discussion (FGD) with 13 speakers representing academia, industry, and government. The results of the analysis of SEM state that the indicators on the industrial clusters, the competitiveness, and the technology transfer have a significant and real contribution to these variables. This research also shows that the industrial clusters and the technology transfer have a direct and significant effect on the competitiveness and the industrial clusters directly and significantly affect the technology transfer. However, the industrial clusters also have an indirect effect on competitiveness through the technology transfer to the shipbuilding industry. The results of the analysis of ISM conclude that the stakeholders involved have the greatest driving force, namely the Ministry of Defense and Ministry of State-Owned Enterprises, while the important factor affected by the stakeholders in strengthening the competitiveness of the shipbuilding industry is the Indonesian Navy Headquarters.
\end{abstract}

(C) 2021 by the authors; licensee Growing Science, Canada. 
for gas carriers and offshore drilling vessels. China receives more bulk orders than other countries, while Japan produces ships that are relatively balanced between container ships, gas carriers, bulk carriers, and tankers. Currently, there are around 250 shipyard units in the country, of which 179 units are capable of building new ships with a total installed capacity of 936,000 DWT (deadweight tons) or 624,000 GT (gross tons) per year (Ma'ruf, 2014). These shipyards are generally small in size, scattered throughout Indonesia. Of these, only 25 units have a capacity of 5,001-50,000 DWT, including four stateowned shipyards, namely: PT. PAL Indonesia, PT. Dok and Perkapalan Kodja Bahari (DKB), PT. Dok and Perkapalan Surabaya (DPS), and PT Industri Kapal Indonesia. The empowerment of national shipbuilding companies through Inpres Number 5 of 2005 or known as the Cabotage Principle, requires all domestic shipbuilding to use Indonesian-flagged fleets. For this reason, a very large replacement of foreign fleets is needed, but in fact, the replacement is almost entirely the purchase of used vessels from abroad because the price is cheap and the contribution of the domestic industry is less than 10\% (Coordinating Ministry For Maritime and Investments Affairs, 2017) with a shipyard capacity as shown in Fig. 1.

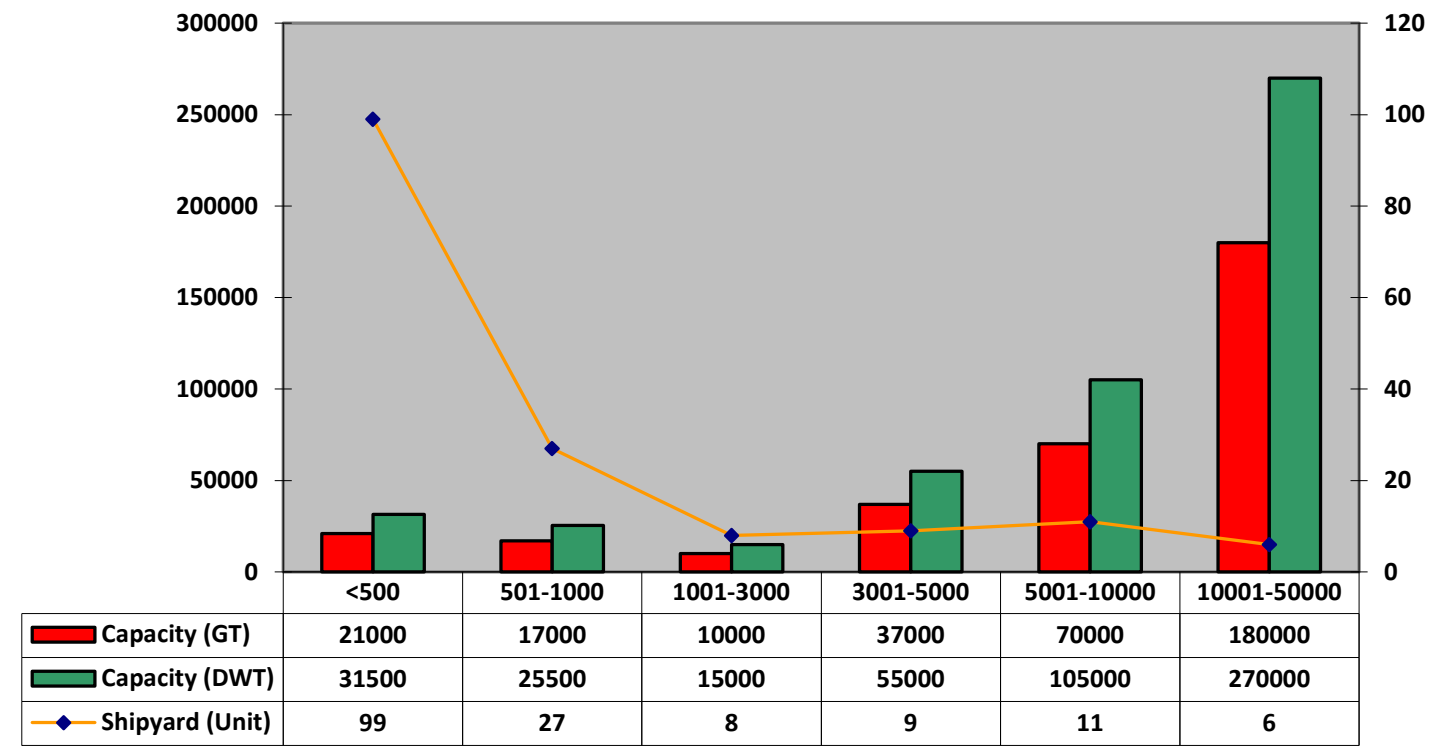

Fig. 1. Shipyard industry capacity

Source: Indonesia Ministry of Industry (2017)

The number of production shipyards in Indonesia is 160 and a production capacity of 1.2 million DWT (Deadweight Tonnage) per year, but the utilization is still low at 35\% (Ministry of Industry, 2017). According to EU-Indonesia Business Network (2019), the shipbuilding commercial shipyards in Indonesia can carry out design and engineering, including the construction of shipbuilding. However, $65 \%$ of the material is imported from abroad and $35 \%$ is supported from within the country. The shipyards of State-Owned Enterprises and other national shipyards have produced warships, however, the manufacture of light frigate-class combat ships is just carried out by PT PAL Indonesia, even though the share of PT PAL in building these ships is still small. Meanwhile, other shipyards only produce auxiliary ships and patrol boats. Domestic supporting industries have not been able to meet the needs of ship engine equipment and electronics. To be able to compete with foreign shipbuilding yards, larger production facilities such as shipyards and other equipment are needed. The ability of human resources also needs to be improved to be able to carry out massive shipbuilding work, so that the work can be carried out efficiently and on time. In advancing the shipbuilding industry, government support is needed because the work is very massive and uses very large costs. According to Zaabi (2015), the shipbuilding industry is very dependent on government policies. In developing the domestic shipbuilding industry, a more comprehensive economic approach is needed. The Diamond Model with a strategic perspective developed by Porter (1990) is an excellent method to determine the competitiveness of a country or business environment at a location because it addresses the important point of the economic model based on its sub-factors. Also, the International Institute of Management and Development (IMD) said that the competitiveness of an economy must be viewed as a whole, because it is influenced by the political, social, and cultural dimensions, therefore the state must prepare an environment with efficient structures, institutions, and policies that encourage the improvement of the company's competitiveness (IMD, 2011). Porter (1996) further suggests that in the process of making a difference in the competitive advantage, a leader must identify established industry rivals, customers, suppliers, potential entrants, and substitute products. Based on Porter's statement, it is necessary to form a defense industrial cluster to gain a competitive advantage.

In this paper, we report about the development of the shipbuilding industry is expected to meet the needs of the Indonesian Navy and the commercial vessels, and to support Indonesia's ocean policy. The purpose of this study is to see the factor that 
influence to the Shipbuilding industry Competitiveness, the influence of Technology Transfer to the Shipbuilding industry Competitiveness, and the influence of the industrial clusters on the Shipbuilding industry Competitiveness, as well as to analyze the institutional model of the Shipbuilding industry Competitiveness.

\section{Materials and methods}

The roadmap for Indonesian ocean policies towards the world's maritime axis is supported in Presidential Regulation Number 16 of 2017 concerning Indonesian ocean Policy which aims to make the ocean sector as the basis for economic development. Indonesia's ocean economic potential is not only in the national waters but also in the jurisdictional waters and the international waters that can be managed following international law. Meanwhile, the TNI's defense equipment can be fulfilled if the domestic shipbuilding industry masters the shipbuilding technology. The Indonesian Ocean Policy is formulated concerning the Indonesian Development Vision as stipulated in Law Number 17 of 2007 concerning the National Long-Term Development Plan 2005-2025 and Law Number 32 of 2014 concerning the ocean affairs and PP No 16 / 2017 regarding the Indonesian ocean policy.

\subsection{Competitiveness (CPT)}

Comparative strategy theory is called "the state competitive advantage" and later became known as the competitive advantage theory of Porter (1990) in which a country cannot succeed based on the industrial isolation; rather, the associated industrial cluster will drive success. According to Porter (1990), the success of a country in a particular industry is driven by four interrelated determinants of competitive advantage. These four determinants include condition factors; demand conditions; related supporting industries; and the company's strategy, structure, and competition. Aruna (2020) explains that the company's competitiveness is determined by the ability of human resources in the form of professional expertise and intellectual strength of each individual. Strategic growth must be associated with higher competitiveness because the ability to pursue the growth domestically or internationally will be an indicator of business health (Sledge, 2005). Porter (1990) argues that a country's success in the industry tends to depend on favorable management practices and the type of organization that matches the source of the industry's competitive advantage. A country gets a Competitive Advantage (CA) if the company (which is in the country) is competitive. According to Porter (1990), competitiveness is also determined by innovation, efficiency, education, foreign capital investment, natural resources, and human factors.

\subsection{Industrial Cluster (IC)}

The cluster includes a variety of related industries and other entities that are important to their competition, including the specialized input suppliers such as components, machines, and services, as well as providing special infrastructure (Porter, 1998) in Bititci (2004); Audretsch and Stephan (1996). Three basic things are characterized by individual clusters, regardless of differences in the structure, size, or sector, first Commonality, Concentration; and Connectivity (Lyon and Atherton, 2000). Meanwhile, Porter (1990) states a cluster as a group of companies and related institutions in certain fields that are geographically adjacent and interrelated due to commonalities and complementary. According to Tu (2011) with various aspects of cooperation and competition, ensuring the industrial clusters create competitive advantages. Wahad (2017) states that the clusters can achieve competitiveness in small and medium enterprises and the clusters improve the company competitiveness by learning in the long term. Kincaid (2005) states that the competitive advantage has an impact on the existence of clusters. Ivarsson and Alvstam (2005) state that in many cases technological developments occur in the industrial clusters. Porter (1990) considers that companies do not only compete with companies in the industry today. However, in the five forces model, it is described that the company is also competing with its potential competitors, namely those who will enter, suppliers, buyers or consumers, and producers of substitute products. And the role of government in this Porter model is to support the shipbuilding industry in the form of policies that can encourage the industry to be more advanced such as tax relief, easy access to capital.

\subsection{Transfer of Technology (IT)}

According to Benedetto (2003), the technology transfer can be defined as a systematic transfer of knowledge for the manufacture of products, for the applications, the processes or providing the services and the international technology transfer from developed countries to developing countries that are sustainable to encourage the industrialization and the economic growth. Gross (2012) and Cunningham (2016) explain that technology transfer is related to bringing the technology from a source of innovation to the market. Heslop et al. (2001) and Lane (2003) explain that the universities play an important role in the complex of Technology Transfer process that facilitates the technological transformation from the pure research activities to the commercialization. The success of Technology Transfer (depends not only on the learning ability of the accepting company but also on the ability of technology providers to overcome the cultural and institutional barriers in the communication. The Transfer of Technology requires the attention of the government, the universities, the industry, and the users. Leydesdorff (2002) said that in the context of the Triple Helix theory, technological innovation is the result of good practice in the interaction between three institutional fields, namely: university-industry-government. According to Kominfo (2015), the constraints for developing countries in implementing TT are the high costs required to 
transfer the technology, and according to Hassan (2015), the most influential factors of the ITT (International Technology Transfer) process are the technology providers and the technology recipient characteristics, the integration of local and foreign actors, the government policies, the cultural differences, the transfer environment, the nature of technology, the mode of transfer, and the management of technology transfer programs.

\subsection{Institutional}

According to Nasution (2002), an institution is a set of rules, procedures, individual behavior norms, and control over resources that simultaneously regulates the relationship between one person and another. The ability of an institution to coordinate and control sources of interdependence among participants is largely determined by the institution's ability to control the resources. Institutional Components (Syahyuti, 2006) are:

1. Person

The people involved in an institution can be identified.

2. Interest

These people are being bound by one interest/goal, so they are forced to interact with each other.

3. Rule

Each institution develops a set of agreements that are held collectively so that one can predict what the behavior of others in the institution is.

4. Structure

Everyone has a position and a role, which must be carried out properly. People cannot change their position on their own accord.

The institutional can also be interpreted as a norm/rule of regulation or organization that facilitates the coordination in shaping each other's views that may be achieved by working together, which includes all social, economic, and cultural institutions, both in the form of an organization, as well as traditions and the existing institutions in society consist of public, private, and non-governmental organizations (Riuntuh \& Minar, 2005).

\section{Research methods}

The research is carried out in several locations: Jakarta, Batam, and Surabaya, which are where the shipbuilding industry is located including the educational institutions, the laboratories, and the Indonesian Navy) institutions as the users of warships.

\section{Table 1}

Focus Group Discussion (FGD) and research respondents.

\begin{tabular}{llll}
\hline Number of FGD & \multicolumn{1}{c}{ Location } & \multicolumn{1}{c}{ Expertise } & \multicolumn{1}{c}{ Respondent/ Resource Person } \\
\hline & $\begin{array}{l}\text { Indonesian Hydrodynamics } \\
\text { Institution / Agency for the } \\
\text { Assessment and Application of } \\
\text { Technology (BPPT) Surabaya }\end{array}$ & $\begin{array}{l}\text { Indonesian Navy } \\
\text { Indonesian Navy } \\
\text { Indonesian Navy } \\
\text { Academics and Researchers }\end{array}$ & $\begin{array}{l}\text { Naval Technological College } \\
\text { Naval seaworthiness Departement } \\
\text { 2nd Fleet Command } \\
\text { Maritime Technology of ITS (Institute } \\
\text { Technology of Sepuluh November) }\end{array}$ \\
& Academics and Researchers & $\begin{array}{l}\text { Shipbuilding System of ITS (Institute } \\
\text { Technology of Sepuluh November) }\end{array}$ \\
& Academics and Researchers & Maritime Technology of ITS (Institute \\
& & Technology of Sepuluh November) \\
& Researchers & Agency for the Assessment and Application of \\
& Academics and Researchers & Technology (BPPT) \\
& Hang Tuah University \\
& Ship Building Industry & PT Dok Perkapalan Surabaya \\
& Ship Building Industry & PT Tesco Indomaritim \\
& Ship Building Industry & PT PAL Surabaya \\
\hline
\end{tabular}

The time of measurement or data collection is conducted in October 2019 - April 2020. This study uses the primary data collected through face-to-face interviews and indirect interviews through a questionnaire with key persons, especially the officials/practitioners in the defense institutions and the researchers/policymakers related to the development of the shipbuilding industry. The population in this study is the entire shipbuilding industry that produces commercial ships and warships, several supporting industries, Government, the educational and research institutions in Jakarta, and Surabaya, either owned by the government or owned by the Indonesian Navy. The number of samples collected is 308 respondents according to the number of samples that must be taken in the study based on the opinion of Hair et al. (1998) and Suharjo and Suwarno (2002) regarding the limitations of the SEM population. The sample is determined purposively. The data collected for ISM is carried out by an expert survey by giving the questionnaires to the experts and conducting a Forum Group Discussion (FGD) of 13 experts in Surabaya on 11 March 2020, especially the officials/practitioners in the defense institutions and the researchers/academics as well as the shipyard industry. The study uses the Structural Equation Modeling (SEM) to test the causality of the model and its hypotheses. The data processing is using Lisrel 8.80 software. This research 
includes the Industry Clusters, the Transfer of Technology, and Competitiveness. This study also uses the Interpretative Structural Modeling (ISM) method by referring to the elements of the innovation system developed by Saxena et al. (1992). Saxena et al. (1992) formulate that there are nine key elements for strengthening/designing an innovation system, but in this study, only six key elements are analyzed. Based on the definition of roots in building the model, the elements involved include (i) stakeholders involved, (ii) stakeholders or groups affected, (iii) program needs, (iv) challenges or constraints faced, (v) changes which are possible / desired, and (vi) required activities. For each key element, sub-elements are defined as the determining factor. The detailed analysis framework using the ISM approach can be seen in Fig. 2. Interpretative Structural Modeling (ISM) analysis in addition to producing key sub-elements, can also identify the hierarchical structure of the relationship between sub-elements and the influence (driver power) of sub-elements to other sub-elements. Key subelements are aspects that have the highest driver power that determines or affects other sub-elements.

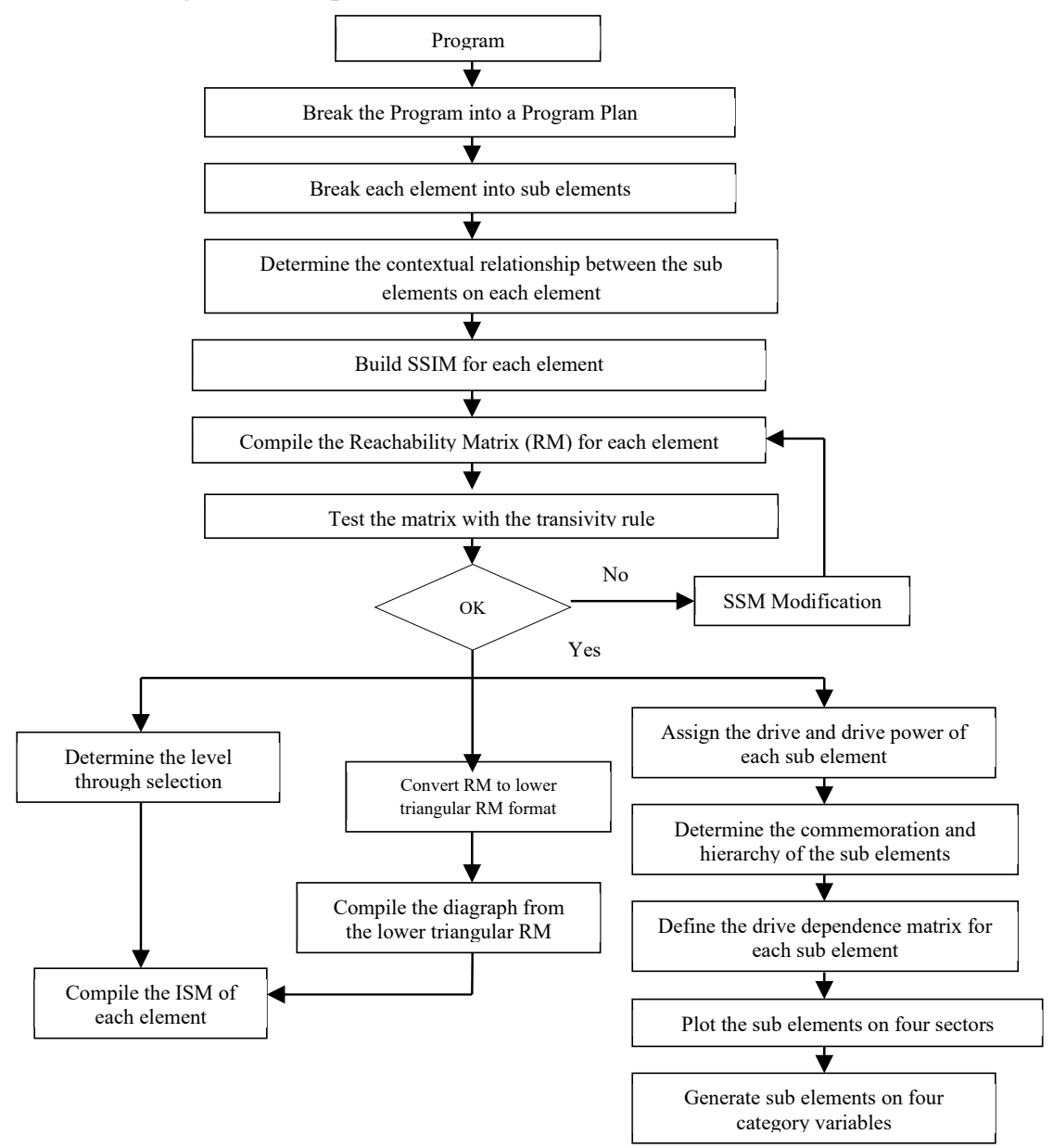

Fig. 2. Analytical Framework uses the ISM approach

Source: Marimin (2004).

\section{Results and discussion}

\subsection{Description of respondant charecteristics}

The types of respondents for the SEM analysis method in this study are divided into 27 clusters consisting of Indonesian Navy; Indonesian Navy Headquarters, Military sealift command, $1^{\text {st }}$ Fleet Command, $2^{\text {nd }}$ Fleet Command, Naval command and staff college, Naval research and development, Naval hydro-oceanographic center, Naval technological college. The shipbuilding industry consists of; PT Ciputra Mitra Sejati, PT Pindad, PT DKB, PT LEN, PT Palindo, PT Krakatau Steel, PT Dock Perkapalan Surabaya, PT Daya Radar Utama, PT DI, PT LIEMS, PT STEADFAST, PT PAL, PT Tesko Indomaritim. The University and research institution; Hasanuddin University, Hydrodynamics Technology Center Agency for the Assessment and Application of Technology (BPPT). And government consist of; Coordinating Ministry of Maritime Affairs, Ministry of Defense, Ministry of Industry, Ministry of Marine and Fisheries. Based on the education level category, it is known that the most respondents come from diploma degree, namely 138 respondents $(44.8 \%)$, master degree as many as 100 respondents $(32.5 \%)$, doctor degree as many as 47 respondents $(15.3 \%)$ and as many as 23 respondents do not answer their final education level (7.5\%). Whereas in the ISM analysis, the questionnaire is given to 13 experts and also they carry 
out the research deepening with FGD with experts consisting of officials/practitioners in the defense institution, researchers, and shipyard directors so that the representation of government, industry, and researcher/university is fulfilled. 4.2 SEM measurement model analysis

Evaluation of the measurement model is carried out on each latent variable by testing the validity and the reliability of the construct. Based on Table 2, it can be seen that all indicator variables meet the validity requirements and have $t$-count value above 1.96. This indicates that all indicator variables are valid to measure the latent construct. However, several indicator variables do not meet the loading factor and t-count value, which means that the variables do not have a significant effect. Hair (2010) and Ghozali (2008) said loading factor $>0,5$ strong enough validation and then below 0,5 it does not affect. Table 2 shows the industrial cluster variable supplier variable indicator showing the loading factor - 0.13 means that the supplier does not affect the industrial cluster and the $t$ value is 1.35 which shows the supplier variable indicator is invalid because $<$ of $t$ table $(1,64$ in alpha $10 \%)$. For Competitiveness variable loading factor variable GOV (0.37) and BO (0.40) below 0.5 , that means they don't affect the variable competitiveness. But the t value of all it indicator are valid they are bigger than $t$ table 1.64. And TT indicator variable is significant, they all bigger than 0.5 , and the $t$ value is valid they are bigger than $t$ table 1.64. After checking the model validity test, the next step is to see the consistency of the model by doing the reliability test. The results of the model reliability test are in Table 3, for each main variable the reliability test results are good, the overall model has good construct reliability (CR) and variance extracted (VE) with CR and VE of $93.9 \%$ and $51.9 \%$ respectively, where the CR and VE values have met the standard provisions which have been declared to be valid. Therefore, it can be concluded that the indicators used in this study can consistently measure the latent construct. And it shows in Table 3 all variable IC, CPT, and TT the construct reliability are good upper 0.7 but the variance extracted are not good they below 0.5 but for the overall model has good. Reliability is a measure of the internal consistency of the indicators of a construct which shows the degree to which each of these indicators shows a general latent construct. The next reliability is the Extracted Variant with a value above or equal to 0.5 . With the provision that the higher value indicates that the indicators correctly represent the latent constructs being developed.

Table 2

SEM Validity Test

\begin{tabular}{|c|c|c|c|c|}
\hline Variable & Indicator Variable & Loading Factor & t-value & Validity \\
\hline \multirow[t]{5}{*}{ Industrial Cluster } & CID & 0.30 & 2.48 & Valid \\
\hline & GIT & 0.65 & 7.61 & Valid \\
\hline & SP & -0.13 & -1.53 & Invalid \\
\hline & BY & 0.71 & 7.66 & Valid \\
\hline & SI & 0.83 & 6.81 & Valid \\
\hline \multirow[t]{5}{*}{ Competitiveness } & $\mathrm{CS}$ & 0.82 & 10.73 & Valid \\
\hline & $\mathrm{CF}$ & 0.93 & 13.53 & Valid \\
\hline & DC & 0.85 & 6.68 & Valid \\
\hline & SID & 0.67 & 9.26 & Valid \\
\hline & GOV & 0.37 & 4.50 & Valid \\
\hline \multirow[t]{5}{*}{ Technology Transfer } & TFS & 0.84 & 11.46 & Valid \\
\hline & SED & 0.87 & 11.07 & Valid \\
\hline & R\&D & 0.86 & 10.55 & Valid \\
\hline & CMP & 0.85 & 9.19 & Valid \\
\hline & ITS & 0.84 & 4.84 & Valid \\
\hline
\end{tabular}

Table 3

SEM Variable Reliability.

\begin{tabular}{lcccc}
\hline \multicolumn{1}{c}{ Variable } & CR & Notes & VE & Notes \\
\hline Industrial Cluster & $94.8 \%$ & Good & $41 \%$ & Not good \\
Competitiveness & $96 \%$ & Good & $43 \%$ & Not good \\
Technology Transfer & $88 \%$ & Good & $40 \%$ & Not good \\
\hline
\end{tabular}

\subsection{Overall Fit Test Model}

The Fit test of the structural model as a whole can be seen from the Goodness of Fit (GoF) measure. A measurement model can be called fit with data if the model can estimate the covariance matrix of the data. The fit measure is expressed as Chi-squared $\left(\chi^{\mathbf{2}}\right) / \mathbf{d f} \leq \mathbf{3}$. The processed data show that the value of Chi-squared $\left(\chi^{\mathbf{2}}\right) / \mathbf{d f}=\mathbf{2 . 4 5 4}$. This means that the measurement model is fit (very good). The CFI value is greater than 0.90, the P-count of the Chi-squared statistic produced by the model is greater than or equal to 0.05 and the RMSEA value is less than 0.08 . Based on the research results, the resulting RMSEA is $(\mathbf{0 . 0 7 9 4})<\mathbf{0 . 0 8}$, which means that the model has met the absolute Fit test criteria for the model at the level of a good fit. The incremental fit model, which is comparing the proposed model with the basic model, is often referred to as the null model or the independent model. It consists of several test tools to determine suitability, namely (a) CFI (Comparative Fit Index), (b) NFI (Normed Fit Index), (c) NNFI (Non-Normed Fit Index), (d) IFI (Incremental Fit Index), (e) RFI (Relative Fit Index). The research results show the measurement values compared to the standard values of the overall model as follows: $\mathrm{CFI}=0.965>0.90, \mathrm{NFI}=0.928>0.90, \mathrm{NNFI}=0.957>0.90, \mathrm{IFI}=0.965>0.90$ and $\mathrm{RFI}=$ 
$0.913>0.90$. All test tools meet the incremental test criteria at the level of good test results (Good fit). The following are the results of the overall Fit test model, which can be seen in Table 4.

Table 4

Results of the Overall Fit Criteria Model.

\begin{tabular}{|c|c|c|c|}
\hline GoF & Cut off Value & Value of Research Result & Notes \\
\hline Chi-square $\left(\chi^{2}\right)$ & Preferably small from Df & 182.59 & Poor fit \\
\hline Df & & 99 & \\
\hline $\begin{array}{l}\text { Chi-square } \\
\left(\chi^{2}\right) / \mathrm{df}\end{array}$ & $\begin{array}{l}\leq 3 \\
(2: 1(\text { Tabachnik and Fidell 2007) and } \\
3: 1 \text { (Kline 2005) }\end{array}$ & 1.844 & Good: good fit \\
\hline Probability (P-value) & $\leq 0.05$ & 0.0000 & Good: good fit \\
\hline RMR & $\begin{array}{l}\text { Good models have a small RMR (Tabachnik and } \\
\text { Fidell 2007). } \leq 0.05 \text { or } 0.08 \text { (Hair et al. 2007) }\end{array}$ & 0.0451 & Good: good fit \\
\hline RMSEA & $\leq 0.08$ & 0.0794 & Good: good fit \\
\hline GFI & $\geq 0.90$ & 0.830 & Not good: marginal fit \\
\hline AGFI & $\geq 0.90$ & 0.800 & Not good: marginal fit \\
\hline CFI & $\geq 0.90$ & 0.965 & Good: good fit \\
\hline NFI & $\geq 0.90$ & 0.928 & Good: good fit \\
\hline NNFI & $\geq 0.90$ & 0.957 & Good: good fit \\
\hline RFI & $\geq 0.90$ & 0.913 & Good: good fit \\
\hline IFI & $\geq 0.90$ & 0.965 & Good: good fit \\
\hline
\end{tabular}

The measure of the Parsimony Fit Model fit is to compare the proposed model with the basic model on all variables in the model that are independent of one another. The parsimony test consists of AGFI (Adjusted Goodness of Fit Index). AGFI is the same as GFI but it has adjusted the effect of degrees of freedom on a model. The research results for the main model give the value of AGFI $=0.800<0.90$ and $\mathrm{GFI}=0.830<0.90$ which means that the parsimony test is not good (Marginal Fit) (Schreiber et al., 2006).

\subsection{The determinant of Shipbuilding Industry Competitiveness Factor Model Analysis}

From the results of data processing and displayed in the form of a structural model image according to the research framework, the influence between variables and t-value which shows the hypothesis is proven or not, with a real level of $10 \%$ for IC to CPT and IC to TT $\mathrm{t}$ - value respectively of 9.50 and $2.98>1.64$ (t-table). And for TT against CPT with a real level of $10 \%$ t-value $1.71>1.64(\mathrm{t}-$ table), so that all hypotheses are proven to include the indirect effect of IC to CPT through TT. The results of hypothesis testing for the structural model in this study can be seen in Table 5. It is found that the Industrial Cluster (IC) variable has a significant effect on Industrial Competitiveness with a direct effect of 0.86 with a t-value of $9.50>$ t-table (1.64). The Industrial Cluster variable (IC) indicator that has a big influence on Industrial Competitiveness (CPT) is Support Industry (SI) of 0.84 with a t-value of 11.43, Buyer/user (BY) of 0.81 with a t-value of 10.88, government Institution (GIT) of 0.69 with a t-value of 8.61 , Core Industry (CID) of 0.33 with a t-value of 3.76 , in the industrial cluster if there is a competition between companies, this competition will increase the competitiveness of these industries, both core, and supporting industries. The researches by Tu (2011), Wahad (2017), Kincaid (2005) support the above hypothesis that the industrial clusters affect competitiveness. Meanwhile, the government institution's role is to support CID such as ease of capital support and fiscal policy support for example tax relief. And buyers here will believe in the domestic production if the quality of the product is better because there is a competition between companies to improve the quality of their products. While the Supplier (SP) from the results of the study shows no significant effect on the industrial competitiveness with a loading factor of -0.13 .

IC also has a direct effect on Technology Transfer (TT) of $\mathbf{0 . 2 9}$ with a t-value of 2.98. Interactions between companies in the industrial clusters lead to the exchange of information and cooperation in improving the quality of products and new products so that the technology transfer also occurs in the industrial clusters. In the industry, there can be collaborative research and product development including design engineering. This cooperation will benefit both parties because the financing burden can be shared. Popov (2016) and Song (2018) say that the government and the foreign investors need to work together in developing the industrial clusters so that the intensive foreign investment (Foreign Direct Investment) has an impact on the technology transfer. Zeller (2001) and Ivarson (2005) say that the transfer of technology and knowledge often occur internationally and do not need to be in adjacent work nets in the clusters.

The effect of Technology Transfer (TT) on Industrial Competitiveness (CPT) is 0.11 with a significant t-value of 1.71 at $10 \%$ alpha greater than t-table (1.64). The research and development and design engineering, if carried out by the industry in the technology transfer program, will produce the products with more advanced technology, so that they will increase the competitiveness of the industry. As explained by Ketels (2003), the interactions, that occur between companies, accelerate the transfer of technology and other benefits that trigger a more dynamic company, including its production chain. In the research of Milton (2012), it is explained that the technology transfer from developed countries is the main source to increase the competitiveness of Brazil, Russia, India, and China. Mathew (2013) says that acquiring foreign technology would increase product competitiveness in the market. 
Thus, the indirect effect of Industrial Cluster (IC) on Industrial Competitiveness (CPT) is also significant. All indicators of Technology Transfer (TT), namely Research and Development (R\&D), Technical Feasibility Study (TFS), Specification and Design Engineering (SED), and Material Collection and Production (CMP), has a significant effect on competitiveness with a loading factor above 0.75 , the largest loading factor is 0.88 on the indicator of Specification and Design Engineering (SED) and the Technical Feasibility Study (TFS) of 0.87. This shows that the process of the transfer of knowledge and technology in the context of developing the shipbuilding industry influences the ability of the industry to grow and develop.

\section{Table 5}

Hypothesis testing results

\begin{tabular}{|c|c|c|c|c|c|c|}
\hline \multirow{2}{*}{$\begin{array}{l}\text { Hypothesis } \\
\text { (Ha) }\end{array}$} & \multirow{2}{*}{ Lane (Relation) } & \multirow{2}{*}{$\begin{array}{l}\text { T-value } \\
(\geq 1.64)\end{array}$} & \multicolumn{3}{|c|}{ Effect } & \multirow{2}{*}{$\begin{array}{l}\text { Hypothesis } \\
\text { Conclusion }\end{array}$} \\
\hline & & & Direct & Indirect & Total & \\
\hline H1 & $\mathrm{IC} \rightarrow \mathrm{CPT}$ & 9.50 & 0.85 & & 0.85 & Accepted \\
\hline $\mathrm{H} 2$ & $\mathrm{IC} \rightarrow \mathrm{TT}$ & 2.98 & 0.29 & & 0.29 & Accepted \\
\hline H3 & $\mathrm{TT} \rightarrow \mathrm{CPT}$ & 1.71 & 0.11 & & 0.11 & Accepted \\
\hline $\mathrm{H} 4$ & $\mathrm{IC} \rightarrow \mathrm{TT} \rightarrow \mathrm{CPT}$ & 9.50 & 0.85 & $0.29 \times 0.11=0.032$ & 0.82 & Accepted \\
\hline
\end{tabular}

Based on the results of variable data processing, a structural model is then built according to the research framework consisting of Industrial Cluster, Technology Transfer, and Competitiveness variables, the magnitude of the influence between variables, and its significance. The structures of the main model completed with the main variables with their respective latent variables and SLF value. In the IC variable, there are two latent variables with small values below 0.5 (Ferdinand, 2000), the weakest loading factor is 0.4. Tabachnik and Fidel (2007) say that the loading factor $>0.5$ is good so that the latent variable of suppliers (SP) with a value of -0.03 and the core industry (CID) of 0.33 can be meant that the core industry and the suppliers have no effect on the industrial clusters, and the influential ones are government institutions (0.69), buyers (BY) (0.81), and supporting industries (SI) (0.84). To increase industrial competitiveness, the role of the government, in this case, is the policy of ease of taxes, capital, and economic stability. Buyers are expected to prioritize the use of domestic products so that the domestic industries can develop. Supporting industries are expected to be able to support the needs for equipment and parts to support the domestic shipbuilding industry, including the availability of raw materials such as steel and other equipment such as electronic equipment for navigation and radio needs, and for warships, of course, very complex weaponry equipment. For the variable of CPT, there are two latent variables with low SLF value below 0.5 , namely Government (0.49) and Business opportunity (BO) (0.34) meaning that these two variables do not significantly affect the competitiveness. In this study, the latent variables that have a direct effect on competitiveness are competition strategy (CS)(0.83), condition factor (CF) (0.92), Deman condition (DC) (0.86), and Support Industry (SID) (0.66). These four latent variables need attention to improving industrial competitiveness. Especially in the shipbuilding industry, to improve competitiveness, it is necessary to increase the research and development capabilities of technology as well as innovation capabilities to produce superior products. In terms of company conditions, the efforts are needed to increase the capacity of human resources through education and training as well as the replacement of better production facilities, precision equipment, and higher capabilities. For the conditions that are high enough for domestic demand for ships, the industry must improve the quality of its production, so that its production is still in demand by domestic users and on the global market. Supporting industries must improve the quality of their products to compete with products from abroad so that the need for ship materials and equipment can be supported by the domestic industry so that the ship production costs can be cheaper by using domestic products.

In the technology transfer variable the SLF value of each latent variable has a significant effect on technology transfer, namely Technical Feasibility Study (TFS) (0.81), Specification Engineering \& Design (SED) (0.88), Research \& Development (R\&D) (0.87), Collecting Material And Production (CMP) (0.82), and Installation Testing \& Submission (ITS) (0.76). To increase the competitiveness of the shipbuilding industry through the technology transfer, all latent variables need attention, because all of these variables are of significant value. The research and development require collaborative research and development in the context of technology transfer. A technical feasibility study is carried out to analyze costs and risks so that the technology to be produced can be carried out effectively and efficiently. In engineering specifications, the design is carried out to suit the operational needs of the user, especially on the warships with the high technical demand. Material collection in ship production is carried out so that the ship production is not disturbed, because it requires very large materials such as steel and electricity networks, the delays in material support will disrupt the ship production time. The final process of shipbuilding is the implementation of testing following the provisions of the classification bureau used and after passing all the testing requirements including partial testing of the new ship's equipment, the handover is carried out to the shipping buyer. The vision of Indonesian maritime affairs is to become a world maritime axis, namely to become a maritime country that is advanced, sovereign, independent, strong, and capable of making a positive contribution to regional security and peace following the national interests. Indonesian maritime policy towards a world maritime axis is supported by 7 pillars and there are 76 main policies contained in the Presidential Regulation Number 16 of 2017 concerning Indonesian Maritime Policy. In this Presidential Regulation, it is stated that the maritime economic policy aims to make "the maritime as the basis for the economic development". In Indonesian maritime policy action plan, it consists of five program clusters, namely: (1) Maritime Boundaries, Ocean Space, and Maritime Diplomacy, (2) 
Shipbuilding industry and Sea Connectivity, (3) Natural Resouces, Maritime Services Industry, and Maritime Environment Management, (4) Maritime Defense and Security, and (5) Maritime Culture.

This research analyzes the determinants of the shipbuilding industry's competitiveness and its institutional model so that it can be an input for the government to advance the shipbuilding industry, in this case, the shipbuilding industry besides that is also to support the defense and security sector, because Indonesia's vast sea area is 5,193,250 $\mathrm{km}^{2}$ (Ramdhan, 2013), so it is prone to pirates and theft of wealth at sea, violation of Indonesian jurisdictions and maritime border conflicts between countries such as in the South China Sea (Meng, 2017). Morrison (2005) states that the ability for surveillance and law enforcement is very limited against the threat of maritime terrorism, illegal fishing, and illegal immigration. Tampi (2017) says that China unilaterally in 2009 has drawn Nine Dots from Spratly Island in the middle of the South China Sea then claimed it as China's Exclusive Economic Zone. This claim overlaps with Indonesia's EEZ which has natural gas reserves of 46 TCF. To secure this area, Indonesia needs warships to balance China's power in the South China Sea, for that it needs a strong shipbuilding industry that can meet the needs of warships for the Indonesian Navy.

President of Indonesia, Jokowi Widodo, states that the sea is the future of national civilization and it is time for the Indonesian nation to see the sea as the source of human life. According to Fortuna (2006) traditionally, the use of Indonesia's oceans is limited to low-level fisheries, trade, and naval power. Now apart from traditional uses, activities in the ocean also include modern fisheries, exploitation of offshore minerals and hydrocarbons, measures for the conservation and protection of the marine environment, maritime communication, and tourism. Kaczynski (2011) explains that the business opportunities related to oceans are very wide and significant, one of which is sea transportation. René L Pattiradjawane (2015) states that as an archipelago in the middle of the Indian Ocean and the Pacific Ocean, Indonesia controls strategic points of sea lines of communication (SLOC) through several Chokepoints in Malacca Strait. To be able to carry out the marine economic activities as described above, it takes the strength of the shipbuilding industry to produce the ships.

\subsection{ISM Measurement Model Analysis}

Based on the results of the SEM analysis, the important points that can be used to formulate an Interpretative Structural Modeling (ISM) analysis such as the sub-elements of program needs. The ISM analysis is the method to find out the form of programs, constraints, and institutions in building the shipbuilding industry. The ISM is a modeling technique developed for strategic policy planning. In the implementation of the ISM method, a discussion with experts (brainstorming) is first carried out to gather ideas consisting of people who understand the ISM concept, understand the problems of developing the shipbuilding industry, have expertise in the industrial sector. From the discussion regarding the industrial development strategy, several ideas or variables will be processed using ISM. Each of these elements will be translated into several subelements and the contextual relationship will be determined so that further pairwise comparisons can be directed. Based on the results of the analysis, it is known that the institutional model and the program to increase the competitiveness of the shipbuilding industry in this study refer to the elements of the innovation system developed by Saxena et al. (1992). Saxena et al. (1992) formulate that there are nine key elements for strengthening/designing an innovation system, but in this study, only six key elements are analyzed. Based on the definition of roots in building the model, the elements involved include (i) stakeholders involved, (ii) stakeholders or groups affected, (iii) program needs, (iv) challenges or constraints faced, (v) changes which are possible/desired, and (vi) required activities. For each key element, sub-elements are defined as the determining factor.

The institutional model is developed from the elements described in Table 6 . The institutional model describes the relationship between the activities and roles of each party to achieve goals and solve obstacles to be faced and strengthen the institutional capacity to strengthen the competitiveness of the shipbuilding industry. Each role has a complementary relationship in meeting program needs, possible changes, and activities required to increase the competitiveness of the shipbuilding industry.

Table 6

Elements and sub-elements of the institutional model.

\begin{tabular}{ccl}
\hline No & \multicolumn{1}{c}{ Element } & \multicolumn{1}{c}{ SubElement } \\
\hline 1 & Stakeholders involved & $\begin{array}{l}\text { Armed Forces of Indonesia Headquarters, Indonesian Navy Headquarters, Ministry of Defense, } \\
\text { Ministry of Industry, Coordinating Ministry of Maritime Affairs and Investation, Supplier, Strategic } \\
\text { Industry, Research Institution, University, Defense Industry Policy Committee, Classification Bureau. }\end{array}$ \\
2 & Stakeholders affected & $\begin{array}{l}\text { Armed Forces of Indonesia Headquarters, Indonesian Navy Headquarters, Ministry of Defense, } \\
\text { Ministry of Industry, Private Company, Strategic Industry, Hydrodynamic Institution / University, } \\
\text { Supporting Industry, Financial Institution. }\end{array}$ \\
3 & Program needs & $\begin{array}{l}\text { Regulatory Support, Research, and Development, Engineering and Design Specification, } \\
\text { Technological Development Cooperation, Financial Institution Support }\end{array}$ \\
4 & Constraints faced & $\begin{array}{l}\text { Political Stability, Economic Stability, Continuity Supply Material, User Satisfaction Level, Trust in } \\
\text { Industry, Industry National Competition, Capital Resources, Human Resources, Policy Consistency, } \\
\text { and Continuity. }\end{array}$ \\
\hline 5 & Possible changes & $\begin{array}{l}\text { High-Quality Product, Military Expenditure, Demand Quantity Local / Global, Offset Policy, } \\
\text { Procurement Procedure, Trust in Industry, Innovation Capability. }\end{array}$ \\
\hline
\end{tabular}




\begin{tabular}{ll}
\hline 6 Activities required & $\begin{array}{l}\text { Research and Development (Internal), Joint Development Program (With Foreign Country), } \\
\text { Improvement of Facilities and Infrastructure (Physical Resources), Cooperation between Industries } \\
\text { (Production), Human Resource Capacity Building. }\end{array}$ \\
\hline
\end{tabular}

\section{6. $\quad$ Stakeholder Involved}

The objective element in the framework of engineering the institutional model of technology transfer and the shipbuilding industry competitiveness program consists of 12 sub-elements, namely 1) Armed Forces Headquarters, 2) Indonesian Navy Headquarters, 3) Ministry of Defense, 4) Ministry of Industry, 5) Coordinating Ministry of Maritime, 6) Supplier (private industry), 7) Strategic Industry (State-Owned Enterprises): PT PAL, PT PINDAD, LEN, 8) related Research and Development Institution (non-ministry)/Hydrodinamic Institution of Agency for the Assessment and Application of the Technology (BPPT), 9) University, 10) Defence Industry Policy Committee (KKIP), 11) Classification Bureau, and 12) Ministry of State-Owned Enterprises. The results of the matrix analysis show that the sub-elements of the Ministry of Defense and Ministry of State-Owned Enterprises are in sector IV (independent), this sub-element is the driver power (the main driving force). Besides, the Indonesian Navy Headquarters is in the position of second driver power as a user of warships produced by shipyards. The role of the Indonesian Navy Headquarters here is to determine the operational needs and the technical specifications of warship technology in the context of military operations and to coordinate with the commitment of defense industry policy as well as the technology and weaponry needs of warships.

\subsection{Stakeholders or Groups Affected}

The stakeholder element or group, that is affected in the institutional design of technology transfer and the shipbuilding industry competitiveness program, consists of nine sub-elements, namely 1) Armed Force Headquarters, 2) Indonesian Navy Headquarters, 3) Ministry of Defense, 4) Ministry of Industry, 5) Private Company / Private Industry, 6) Strategic Industry (State-Owned Enterprises), 7) LHI (Hydrodynamics Institution) / University, 8) Supporting Industry, and 9) Financial Institution. The results of the analysis with the ISM system in the form of a power-dependence driver matrix for the objective elements which show that the sub-Headquarters of the Indonesian Navy is in sector IV (independent), this sub-element is the driver power (the biggest driving force. This means that any activity related to increasing the capability of the shipbuilding industry will have an immediate effect on the Indonesian Navy Headquarters. The main factor or key is at the Indonesian Navy Headquarters.

\subsection{Program Needs}

The elements of program needs involved in the technology transfer institutions and the shipbuilding industry competitiveness programs consist of six sub-elements, namely 1) Regulatory Support, 2) Research and Development, 3) Engineering Specification and Design, 4) Technology Development Cooperation, 5) Financial Institution Support, and 6) Long Term Program. The results of the matrix analysis show that the sub-elements of Regulatory Support and Long-Term Program are in sector IV, which means that these sub-elements are driver power (the biggest driving force). It can be concluded that the program needs to improve the competitiveness of the shipbuilding industry with regulatory support and the long-term program. Although the issue of world maritime affairs exists in Indonesia, however, the shipbuilding industry can be said to be not very good, because there is no regulatory support from the government starting from fiscal policies in the form of tax ease and capital assistance and long-term program for ordering ships, so that the shipbuilding industry continues to get the long-term ship orders.

\subsection{Challenges / constraints faced}

The constraints faced in the technology transfer institutional model and the shipbuilding industry competitiveness program consist of 10 sub-elements, namely 1) Political Stability, 2) Economic Stability, 3) Continuity of Supply Material, 4) Material Quality, 5) Level of User Satisfaction, 6) Trust in the Industry, 7) Industry National Competition, 8) Capital Resources, 9) Human Resources, and 10) Policy Consistency and Continuity. The results of the matrix analysis show that the sub-elements of Policy Consistency and Continuity are in sector IV (independent). This sub-element is stated as driver power, which means that the obstacles faced for determining the competitiveness of the shipbuilding industry are policy consistency and continuity. Consistency of policy is an obstacle that is often faced by Indonesia, this is because the period of government leadership in Indonesia is only about 5 or 10 years and usually a change of policy occurs when there is a change in leadership. Of course, this can hamper the development of the shipbuilding industry. Because if you are going to build a strong shipbuilding industry, a policy must be consistent and sustainable. This consistency is needed so that when the power changes, the program can be continued.

\subsection{Activities required}

The activity elements needed in the technology transfer institutional model and the shipbuilding industry competitiveness program consist of six sub-elements, namely 1) Research and Development (internal), 2) Joint Development Program (with foreign countries), 3) Improvement of Facilities and Infrastructure (Physical Resources), 4) Cooperation between Industries 
(production), 5) Human Resource Capacity Building, and 6) Improvement of Fiscal Policy and Independence. The results of the matrix analysis which states that the Research and Development (internal) sub-elements are in sector IV (independent). The sub-element is the driver power (the biggest driving force). That is, the activities needed to determine the competitiveness of the shipbuilding industry are Research and Development (internal).

\section{Conclusion}

Based on the results of the research analysis, the conclusions are :

1. Factors that influence and contribute to the competitiveness of the shipbuilding industry are the Condition Factor (CF), especially the shipbuilding industry facilities and infrastructure and ship design capabilities, then followed by Deman Condition (DC), namely the level of satisfaction of using domestically-made vessels and the quality of domesticallyproduced vessels, Strategy, Structure and Competitive Companies (CS), especially the ability to innovate the domestic shipbuilding industry and company management, and Support and Correlated Industry (SID), namely local supporting industries that provide fast and cost-efficient supply and technological development cooperation.

2. Industrial Clusters (IC) which have a significant direct effect on the competitiveness of the shipbuilding industry with indicators that have a significant effect are Supporting Industries (SI), Buyers / Users (BY), and Government Institutions (GIT), while IC also has a direct influence on Technology Transfer (TT) and Technology Transfer (TT) also affects Industrial Competitiveness (CPT) and Industrial Clusters (IC) on Industrial Competitiveness (CPT) in the shipbuilding industry through TT.

3. The institutional model and program activities to increase the competitiveness of the shipbuilding industry show that the stakeholders involved have the greatest driving force, namely the Ministry of Defense and Ministry of State-Owned Enterprises, while the important factor affected by the stakeholders in strengthening the competitiveness of the shipbuilding industry is the Indonesian Navy Headquarters. The shipbuilding industry needs a long-term program so that the sustainability of the shipbuilding industry will be maintained and the skills of the labor will be maintained. Regulatory support in the form of fiscal in the form of tax relief and easy access to capital is urgently needed by the shipbuilding industry to improve competitiveness. The important factors facing the constraints are the consistency of policies and continuity. Changes made possible by the strengthening of industrial competitiveness are high-quality products and innovation capabilities, while the elements of activity that is needed is a continuous Research and Development program.

\section{Ackowledgement}

The authors greatly acknowledge the support from Bogor Agricultural University (IPB University) Bogor, Indonesia for providing the necessary resources to carry out this research work. The authors are also grateful to the anonymous reviewers and journal editorial board for their many insightful comments, which have significantly improved this article.

\section{References}

Arshad, M. Z., Ahmad, M. J., Ali, M., \& Khan, W. A. (2020). The role of government business support services and absorptive capacity on SMES performance. International Journal of Advanced Science and Technology, 29(3), 14921499.

Aruna. (2020). Factor affecting the competitive capability of small and medium woman intrapreneurs. International Journal of Advanced Science and Technology, 29(5s), 574-584.

Audretsch, D. B., \& Stephan, P. E. (1996). Company-scientist locational links: The case of biotechnology. The American Economic Review, 86(3), 641-652.

Di Benedetto, C. A., Calantone, R. J., \& Zhang, C. (2003). International technology transfer. International Marketing Review, 20(4), 446-462.

Bititci, U. S., Martinez, V., Albores, P., \& Parung, J. (2004). Creating and managing value in collaborative networks. International Journal of Physical Distribution \& Logistics Management, 34(3/4), 251-268.

Cunningham, P., Jakob, E., \& Abdullah, G. (2016). Handbook of Innovation Policy Impact. Cheltenham (UK): Edward Elgar Publishing.

Gross, J.N. (2012). Performance-Based Internet Reward System. US Patent App. 13/348, 330.

Hair, J. (1998). Multivariate Data Analysis, Fifth Edition. New Jersey (US): Prentice-Hall.

Hassan, A. (2015). International technology transfer models: A comparison study. Journal of Theoretical and Applied Information Technology, 78(1).

Heslop, L. A., McGregor, E., \& Griffith, M. (2001). Development of a technology readiness assessment measure: The cloverleaf model of technology transfer. The Journal of Technology Transfer, 26(4), 369-384.

IMD. Institute of Management and Development. (2011). World Competitiveness Yearbook. Methodology in a Nutshell.

Ivarsson, I., \& Alvstam, C.G. (2005). The effect of spatial proximity on technology transfer from tncs to local suppliers in developing countries: The case of AB Volvo in Asia and Latin America. Economic Geography, 81(1), 83-111.

Schreiber, J. B., Nora, A., Stage, F. K., Barlow, E. A., \& King, J. (2006). Reporting structural equation modeling and confirmatory factor analysis results: A review. The Journal of Educational Research, 99(6), 323-338. 
Ketels, C.H.M. (2003). The Development of the Cluster Concept-Present Experiences and Further Developments. Duisburg (DE): Prepared for NRW Conference on Clusters.

Kincaid, B.L. (2005). Competitive Advantage of Clusters Within Lesser Developed Countries of the South Pacific: An Empirical Case Study Extending the Porter Diamond Model. Minnesota (US): Capella University.

Lane, J. P. (2003). The state of the science in technology transfer: Implications for the field of assistive technology. The Journal of Technology Transfer, 28(3-4), 333-354.

Leydesdorff, L. (2002). The Triple Helix of University-Industry-Government Relations. Encyclopedia of Creativity, Innovation, and Entrepreneurship. New York (US): Springer.

Lloyds' List Intelligence. (2018). Shipbuilding Outlook Report.

Lyon, F., \& Atherton, A. (2000). A Business View of Clustering: Lessons for Cluster Development Policies. Foundation for SME Development.

Ma'aruf. (2014). Inovasi Teknologi untuk Mendukung Program Tol Laut dan Daya Saing Industri Kapal Nasional. Seminar Nasional Teknologi Terapan.

Ma'ruf. (2014). Strategi Pengembangan Industri Kapal Nasional Berbasis Teknologi Produksi dan Pasar Domestik. Jakarta (ID): BPPT Press.

Marimin. (2004). Pengambilan Keputusan Kriteria Majemuk. Jakarta (ID): PT. Gramedia Widia Sarana Indonesia.

Morrison. (2005). Power, Control, and Denial: Australian Maritime Defence Strategy and Australia's Oceans Policy. Maritime Study. 2005.

Meng, LY. (2017). Sea of Cooperation or Sea of Conflict: The South China Sea in the Context of China-ASEAN Maritime Cooperation. International Journal of China Studies South China Sea in the Context of China-ASEAN Maritime Cooperation, 321, 8(3), 321-345.

Nasution. (2002). Pengembangan Kelembagaan Koperasi Pedesaan untuk Agroindustri. Bogor (ID): IPB Press.

Pattiradjawane, René L. (2015). South China Sea Disputes: Sovereignty and Indonesian Foreign Policy. DR-NTU. No. 116 - 13 May 2015.

Porter, M.E. (1990). The Competitive Advantage of Nation. The President and Fellows Harvard College. All Rights Reserved. Harvard Business Review.

Porter, M.E. (1996). Competitive Advantage, Agglomeration Economies, and Regional Policy. International Regional Science Review, 19(1-2), 85-90.

Ramdhan. (2013). Aplikasi Sistem Informasi Geografis dalam Penilaian Proporsi Luas Laut Indonesia. Journal Ilmiah Geomatika, 19(2), $141-146$.

Riuntuh and Minar. (2005). Kelembagaan dan Ekonomi Rakyat. Yogyakarta (ID): BPFE Yogyakarta.

Sledge, M. (2005). Soldier Dead: How We Recover, Identify, Bury, and Honor Our Military Fallen. New York (US): Columbia University Press.

Suharjo, B., \& Suwarno. (2002). Model Persamaan Struktural, Teori dan Aplikasinya. Bogor (ID): IPB Press.

Syahyuti, (2006). 30 Konsep Penting dalam Pembangunan Pedesaan dan Pertanian. Jakarta: Bina Rena Pariwara.

Saxena, J. P., \& Vrat, P. (1992). Hierarchy and classification of program plan elements using interpretive structural modeling: a case study of energy conservation in the Indian cement industry. Systems practice, 5(6), 651-670.

Tampi, B. (2018). Konflik Kepulauan Natuna antara Indonesia Dengan China (Suatu Kajian Yuridis). Jurnal Hukum Unsrat. 2017. 23(10), July-December/2017.

Tu, H. (2011). Cluster Marketing Models and Strategies: the Implications. Thereof in the Chinese High-Tech Industry. China: International Journal of China Marketing, Wu Han Institute of Technology, 1(2), 33-44.

Kaczynski, W. (2011). The future of blue economy: lessons for European Union. Foundations of Management, 3(1), 2132 .

Wahad, I.M. (2017). The effect of clustering on competitiveness improvement in Hebron: A structural equation modeling analysis. Journal of Manufacturing Technology Management, 28(5).

Wulan. (2020). Application of Analytical Hierarchy Process (AHP) in determining maritime defense strategy as a followup to conflict in the Natuna Sea. International Journal of Advanced Science and Technology, 29(3s), (2020), $382-394$.

Zaabi, A.R. (2015). Strategic corporate governance stakeholder complexities in strategic decision implementation: The shipbuilding industry in Abu Dhabi. The Journal of Developing Areas, 49(6), 235-246.

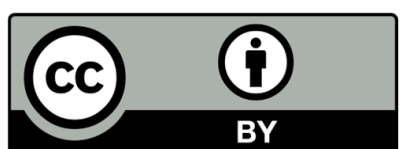

C 2021 by the authors; licensee Growing Science, Canada. This is an open access article distributed under the terms and conditions of the Creative Commons Attribution (CC-BY) license (http://creativecommons.org/licenses/by/4.0/). 